mgr inz. Mieczyslaw Stypka

mgr inz. Jarostaw Iwanowski

mgr inz. Marcin Haba

Instytut Pojazdów Szynowych ,TABOR”

\title{
Układ diagnostyki w systemie sterowania zmodernizowaną lokomotywą EU07A
}

\begin{abstract}
W niniejszym artykule przedstawiono strukturę sprzętowa mikroprocesorowego uktadu sterowania i diagnostyki zmodernizowanej lokomotywy EU07A. Omówiono system komunikacji, przedstawiono główne funkcje realizowane przez układ sterowania i diagnostyki. Zaprezentowano przyklady wykorzystania danych $z$ układu diagnostycznego w rozwiazywaniu wybranych problemów technicznych. Przedstawiono przebiegi wybranych sygnatów ilustrujace działanie uktadu diagnostyki. Omówiono elementy uktadu diagnostycznego zaimplementowanego $w$ panelu operatorskim na potrzeby maszynisty oraz serwisu.

Artykut powstat $w$ wyniku realizacji projektu badawczego pt. „Prognozowanie stanu technicznego głównych systemów pojazdu szynowego na podstawie analizy zmian wartości charakterystycznych parametrów podzespołów" finansowanego przez Ministerstwo Nauki i Szkolnictwa Wyższego (nr projektu N N509 336637 z dnia 28.08.2009).
\end{abstract}

\section{Wprowadzenie}

Lokomotywa EU07A, której modernizacja została zrealizowana wspólnie przez Instytut Pojazdów Szynowych „TABOR” w Poznaniu i ZNTK Oleśnica S.A. jest lokomotywą nowoczesną [1]. Składa się na to zastosowanie układów biegowych $\mathrm{z}$ nowymi asynchronicznymi silnikami trakcyjnymi o większej mocy, które przystosowano do prędkości $160 \mathrm{~km} / \mathrm{h}$. W pudle pojazdu wymieniono wszystkie urządzenia i zastosowano nowoczesną aparaturę wyposażoną $\mathrm{w}$ lokalne sterowniki mikroprocesorowe. Lokomotywa wyposażona jest w mikroprocesorowy system sterowania komunikujący się za pośrednictwem sieci CAN i umożliwiający również pełną diagnostykę pojazdu.
2. System sterowania i diagnostyki lokomotywy Mikroprocesorowy system sterowania i diagnostyki lokomotywy EU07A tworzą:

- panel operatorski w kabinie 1

- panel operatorski w kabinie 2

- sterownik pulpitowy 1

- $\quad$ sterownik pulpitowy 2

- sterownik przetwornicy

- sterowniki napędu i hamowania ED

- sterownik tablicy pneumatycznej

- sterownik układu przeciwpoślizgowego

- sterownik układu uzdatniania powietrza

- sterownik pośredniczący CPU723-T

- sterownik prędkościomierza (rejestratora)

- sterownik diagnostyczny HUB oraz modem GSM

- $\quad$ sterownik jazdy uproszczonej.

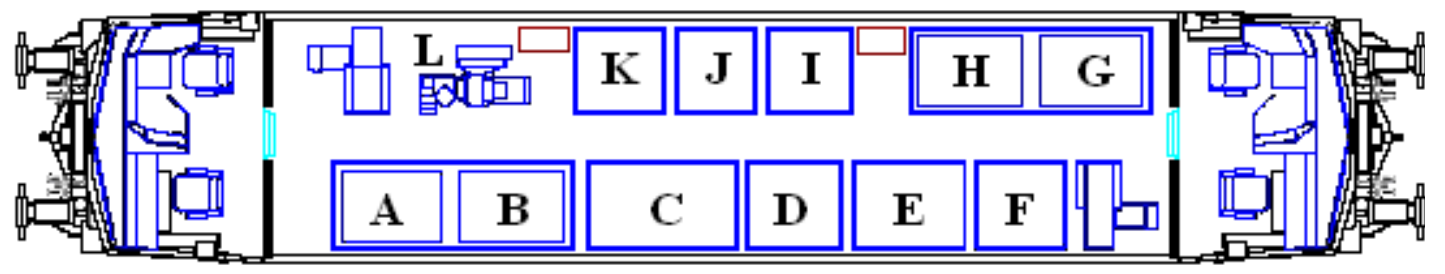

Rys. 1. Rozmieszczenie urządzeń na lokomotywie

Na rys. 1 przedstawiono rozmieszczenie poszczególnych urządzeń na pojeździe: A - Falownik 1, B - Falownik 2, C - Szafa rozdzielcza WN, D - Opornik hamowania 1, E - Przetwornica pomocnicza, F - Szafa elektroniki (UPP IPS, UPP MEDCOM), G - Falownik 3, H - Falownik 4, I - Szafa rozdzielcza, J - Tablica pneumatyczna, K - Opornik hamowania 2, L - Moduł uzdatniania powietrza. 
Komunikacja pomiędzy poszczególnymi elementami systemu odbywa się za pośrednictwem magistrali CAN podzielonej na trzy sekcje.

- CAN 1: sterowniki układu napędowego i przeciwpoślizgowego (MEDCOM)

- CAN 2: sterowniki manipulatorów, sterownik tablicy pneumatycznej, sterownik jazdy uproszczonej

- CAN 3: prędkościomierz (UniControl), sterowniki przetwornic (ENIKA), sterownik układu przeciwpoślizgowego (IPS), panele operatorskie maszynisty, sterowniki pulpitowe, sterownik szafy NN, sterownik układu uzdatniania powietrza, sterownik tablicy pneumatycznej, sterownik jazdy uproszczonej.

Na pulpicie pomocnika w kabinie 2 zabudowane są gniazda diagnostyczne umożliwiające łatwy dostęp do poszczególnych segmentów sieci CAN przez obsługę serwisową.

Transmisja ramek pomiędzy poszczególnymi magistralami CAN realizowana jest przez następujące elementy pośredniczące:

- CAN $1 \leftrightarrow$ CAN 2: sterownik pośredniczący CPU723-T firmy SELECTRON

- CAN 2 < CAN 3: konwerter I-7532 (Two-channel CAN Bus Bridge) firmy ICP DAS.

System sterowania i diagnostyki lokomotywy EU 07A realizuje następujące funkcje:

- jazdę normalną

- jazdę w trybie uproszczonym
- diagnostykę lokalną (panele operatorskie maszynisty)

- diagnostykę zdalną (sterownik diagnostyczny HUB oraz modem GSM).

Do trybu jazdy uproszczonej można przejść w przypadku awarii paneli i sterowników pulpitowych.

\section{Diagnostyka lokalna $z$ poziomu panelu opera- torskiego maszynisty}

Załączenie panelu operatorskiego następuje po załączeniu rozrządu lokomotywy w danej kabinie. Po uruchomieniu systemu pojawia się ekran powitalny będący również ekranem wstępnej diagnostyki wszystkich podstawowych elementów lokomotywy przedstawionych na rys. 1. Gdy system wykryje w wyżej wymienionych elementach błąd następuje wyświetlenie informacji „BRAK ZEZWOLENIA NA JAZDĘ". W przypadku gdy wszystkie systemy są sprawne wyświetlona zostaje informacja „ZEZWOLENIE NA JAZDĘ”. Po przejściu zakładki powitalnej i zezwoleniu na jazdę zostaje wyświetlony ekran główny „Jazda” przedstawiony na rys. 2.

$\mathrm{Na}$ ekranie tym przedstawione są wartości prądów trakcyjnych [A], napięcia trakcyjnego [kV], prędkości $[\mathrm{km} / \mathrm{h}]$, siły zadanej $[\mathrm{kN}]$, siły realizowanej $[\mathrm{kN}]$, potwierdzenie wybranego kierunku oraz ograniczenia prędkości. Na ekranie głównym znajdują się kontrolki przedstawiające stan wybranych aparatów jak np. odbieraki, wyłącznik szybki, wentylatory, sprężarki itp.

$\mathrm{Na}$ pasku w dolnej części ekranu znajdują się przyciski wyboru poszczególnych zakładek:

„Jazda”, „Aktual. kom.”, „Opcje”, „Wył. nadpr.”, „Diag. światel”, „Tablica pneum.”, „Diag. układu”, „Próby ham.”, „Rejestr awarii”, „Powrót” - powrót do ekranu głównego.

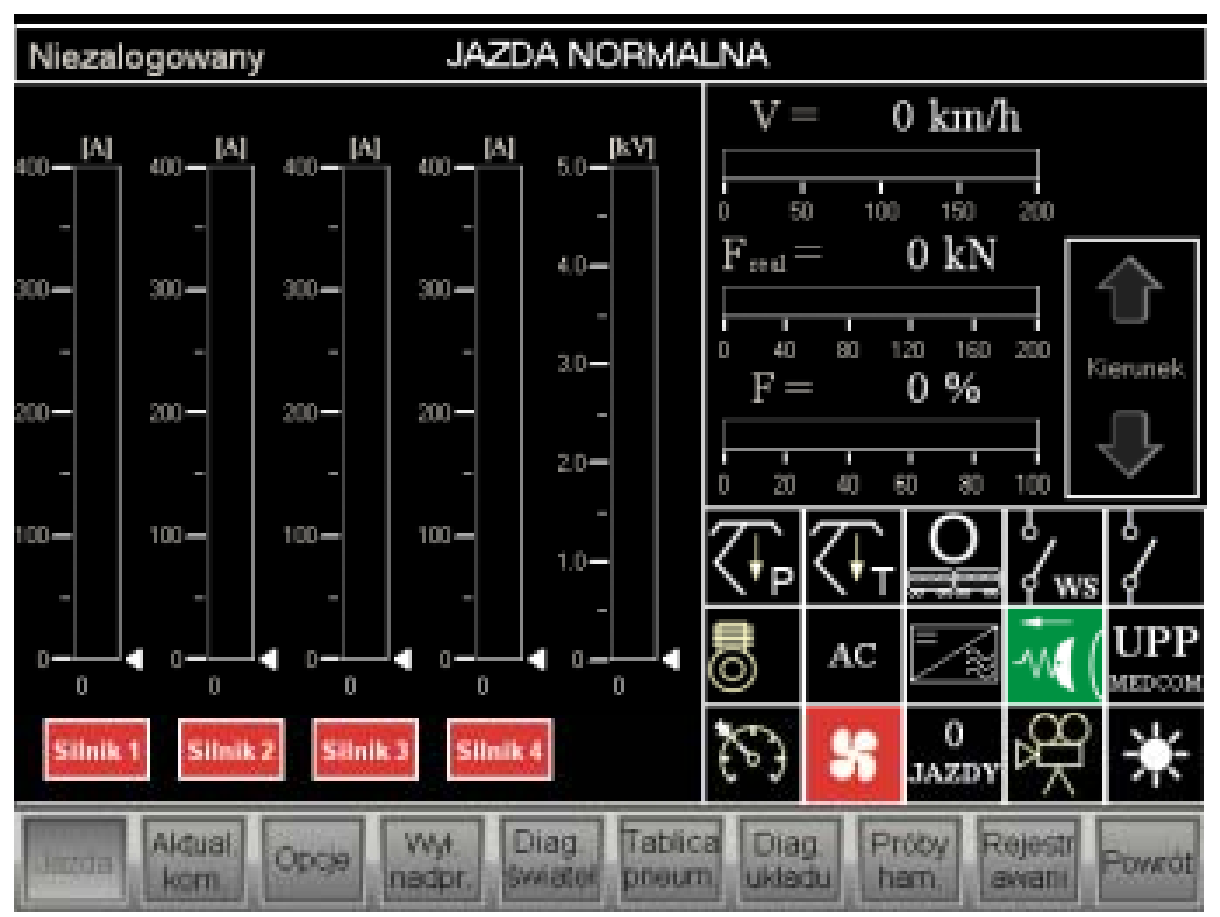

Rys. 2. Ekran główny prezentowany na panelu maszynisty 
Ekran „Aktualne komunikaty” służy do podglądu bieżących stanów awaryjnych oraz powiadomien. W ramce pod napisem „Zdarzenie” wyświetlone zostają ogólne błędy dotyczące całego pojazdu oraz zakomunikowane błędy danego elementu. Aby zobaczyć dokładniejszy opis należy nacisnąć przycisk z danym elementem umieszczony na dole ekranu:

a) „Falownik” - diagnostyka falowników

b) „Pulpit” - diagnostyka pulpitów

c) „RWN” - Rozdzielnia Wysokiego Napięcia

d) „Szafa NN" - Szafa Niskiego Napięcia

e) „UZD” - Uzdatnianie powietrza

f) „UPP”- Układ przeciwpoślizgowy IPS

g) „Przetw. Pomoc.” - przetwornica pomocnicza

h) „Tab. Pneum.” - tablica pneumatyczna.

Ekran „Opcje” służy do wyboru dodatkowych funkcji na postoju lokomotywy:

„Test” - test smarowania obrzeży kół oraz załączanie i wyłączanie samego smarowania.

„Test lampek” do sprawdzania poprawności wszystkich lampek pulpitowych. Po naciśnięciu przycisku lampki załączają się na $10 \mathrm{~s}$ po czym gasną.

„Wentylatory silników trakcyjnych" mający na celu załączenie z pełną prędkością obrotową wentylatorów silników trakcyjnych na postoju. Opcja ta może zostać załączona wyłącznie w przypadku neutralnej pozycji jazdy.

„Rozruch pod górę" umożliwiający ruszenie lokomotywy ze składem w przypadku postoju na wzniesieniu.

„Zmiana średnicy obręczy | Zerowanie przetoczenia" powodujący przejście do kolejnego okna.

Ekran „Wyłączniki nadprądowe” zawiera stan wyłączników nadprądowych. Poszczególne wyłączniki oznaczone są symbolami schematowymi oraz opisem pojaśniającym, którego elementu dotyczą. Jeżeli kolor napisu jest czerwony to dany wyłącznik nie jest załączony, natomiast kolor zielony oznacza, że wyłącznik jest załączony.

Ekran „Diagnostyka światel pojazdu” prezentuje, które światła i w jakiej pozycji zostały załączone. Światła lokomotywy będą diagnozowane poprzez wizualizacje odpowiednich stanów. Poszczególne elementy będą zmieniały swój kolor w zależności od załączonego światła (światło białe, światło czerwone).

Ekran „Tablica pneumatyczna" przedstawia schemat tablicy pneumatycznej wraz z następującymi wskazaniami:

- stopień hamulca zespolonego (w zakresie od 0 do 11)

- $\quad$ stopień hamulca dodatkowego (w zakresie od 0 do $100 \%$ )

- zadziałanie hamulca bezpieczeństwa

- wartość ciśnienia w przewodzie głównym
- wartość ciśnienia w zbiorniku sterującym

- wartość ciśnienia w zbiorniku rozrządu

- wartości ciśnień w cylindrach hamulcowych wózków A i B.

W dolnej części ekranu znajdują się dwa przyciski „Sprężarki główne” i „Sprężarka pomocnicza". Po naciśnięciu danego przycisku przechodzi się do kolejnych zakładek z danymi dotyczącymi wybranej sprężarki.

Ekran „Diagnostyka ukladu” przedstawia schemat rozmieszczenia poszczególnych elementów systemu sterowania. W razie jakiegokolwiek konfliktu któregoś z elementów następuje podświetlenie danego bloku na czerwono. Kolejnym elementem, na który warto zwrócić uwage jest tabela zatytułowana „Brak ramek". W przypadku, gdy któraś z ramek CAN nie jest przesyłana do panelu operatorskiego, jej nr i opis zostaje wyświetlony w tym okienku.

Po wybraniu odpowiedniej zakładki wyświetlane są ekrany dotyczące poprawność pracy takich elementów systemu jak:
a) napęd trakcyjny
b) układ przeciwpoślizgowy
c) tablica pneumatyczna
d) sterownik manipulatora $1 / 2$
e) układ uzdatniania powietrza
f) przetwornica pomocnicza
g) prędkościomierz
h) szafa NN
i) sterownik pulpitowy $1 / 2$.

Ekran „Próby ham.” umożliwia maszyniście przeprowadzenie następujących prób:

1. Próba "Sygnałów pulpitowych"

2. Próba "Szczelności lokomotywy"

3. Próba „Szczelności pociąu”

4. Próba "Szczelności pociąu towarowego"

5. Próba "Manipulatora hamulca zespolonego"

6. Próba "Manipulatora hamulca dodatkowego"

7. Próba „Hamulca pneumatycznego"

8. Próba „Hamulca elektrodynamicznego"

9. Próba „Hamulca zespolonego - automatyczna"

10. Próba „Hamulca dodatkowego - automatyczna".

Ekran „Rejestr awarii”, jest dziennikiem wszelkich komunikatów, awarii i powiadomień. W zależności od priorytetu komunikat może być wyświetlony $\mathrm{w}$ kolorze zielonym, żółtym lub czerwonym (od najmniej do najbardziej ważnego). Wraz z komunikatem zapisany zostaje czas wystapienia danego zdarzenia.

\section{Diagnostyka zdalna przez sieć GSM}

Modemy GSM umożliwiają przesyłanie danych na rozległym obszarze obejmującym zasięg działania sieci danego operatora. Zastosowanie transmisji GSM eliminuje konieczność przebywania na pojeździe 
pracownika oddelegowanego jedynie w celu zebrania danych diagnostycznych z pojazdu znajdującego się często kilkaset kilometrów od siedziby firmy. Pozwala również zminimalizować koszty i racjonalnie wykorzystać czas pracy pracowników, gdyż zbieranie danych diagnostycznych odbywa się automatycznie, 24h / dobę, bezpośrednio na komputer znajdujący się w naszym biurze a koszty zakupu modemu i opłacenie abonamentu nie przekraczają wydatków związanych z kilkoma wyjazdami służbowymi pracowników. Jedynym minusem jest to, że polscy operatorzy komercyjnych sieci GSM nie oferuja 100\% pokrycia szlaku kolejowego. Szczególnie do omawianego zastosowania nadawałby się kolejowy system GSMRail, który w Polsce jest jednak dopiero w początkowej fazie wdrażania [2].

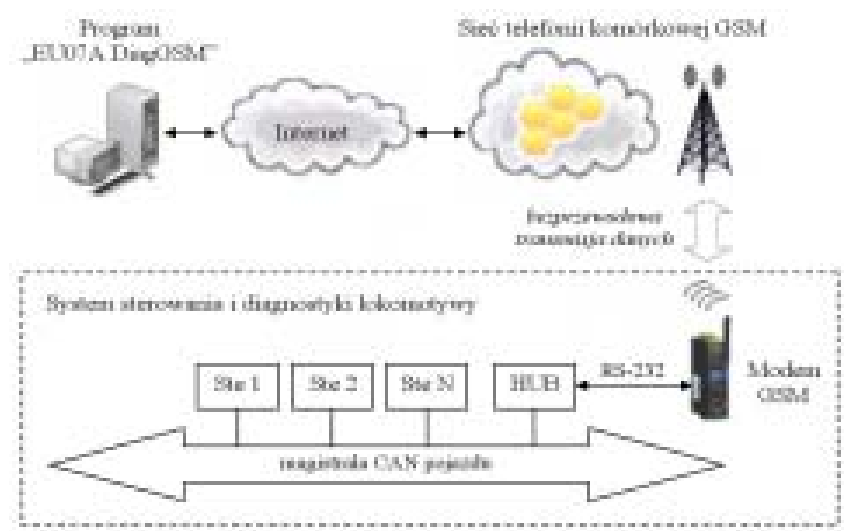

Rys. 3. Tor zdalnej transmisji danych z lokomotywy do centrum diagnostycznego za pośrednictwem sieci GSM

W rozwiązaniu wdrożonym na lokomotywie EU07A zastosowano modem OnCell G3150 firmy MOXA. Jest to komórkowy modem IP w wykonaniu przemysłowym umożliwiający bezprzewodową komunikację $\mathrm{z}$ urządzeniami wyposażonymi $\mathrm{w}$ port szeregowy znajdującymi się $\mathrm{w}$ trudnodostępnych lokalizacjach [3]. Modem może pracować w sieciach
GSM / GPRS / EDGE w czterech pasmach częstotliwości: 900 / $1800 \mathrm{MHz}$ (Europa), 850 / $1900 \mathrm{MHz}$ (USA). Po zainstalowaniu sterownika „MOXA OnCell Windows Driver Manager" na komputerze $\mathrm{z}$ dostępem do Internetu port szeregowy modemu widoczny jest jako wirtualny port COM komputera.

Tor zdalnej transmisji danych diagnostycznych $\mathrm{z}$ lokomotywy do centrum diagnostycznego za pośrednictwem sieci GSM przedstawiono na rys. 3 .

Sterownik HUB odbiera wszystkie ramki z magistrali CAN i na ich podstawie tworzy ramkę diagnostyczną zawierającą informacje dotyczące całego systemu sterowania (ponad 1800 parametrów diagnostycznych!). Ramka diagnostyczna przesyłana jest co 100 ms do modemu GSM - za pośrednictwem interfejsu RS-232 jako ciag 500 znaków ASCII. Modem GSM retransmituje odebrane ramki do komputera pełniącego rolę centrum diagnostycznego. Odbiór danych diagnostycznych z wirtualnego portu COM komputera realizowany jest przez aplikację diagnostyczną „EU07A DiagGSM”.

Na rys. 4 przedstawiono wygląd okna programu „EU07A DiagGSM”. Program ten realizuje następujące funkcje:

1. obsługa wirtualnego portu COM stowarzyszonego z modem GSM (otwarcie / zamknięcie portu)

2. odbiór ramki z danymi diagnostycznymi z portu szeregowego komputera i dekodowanie jej zawartości z ciągu znaków ASCII na wartości poszczególnych danych diagnostycznych

3. wizualizacja danych diagnostycznych odbieranych z systemu modułów diagnostycznych

4. archiwizacja danych diagnostycznych odbieranych ze sterownika - zapis wartości danych diagnostycznych do pliku tekstowego o formacie nazwy gwarantującym jego jednoznaczną identyfikację.

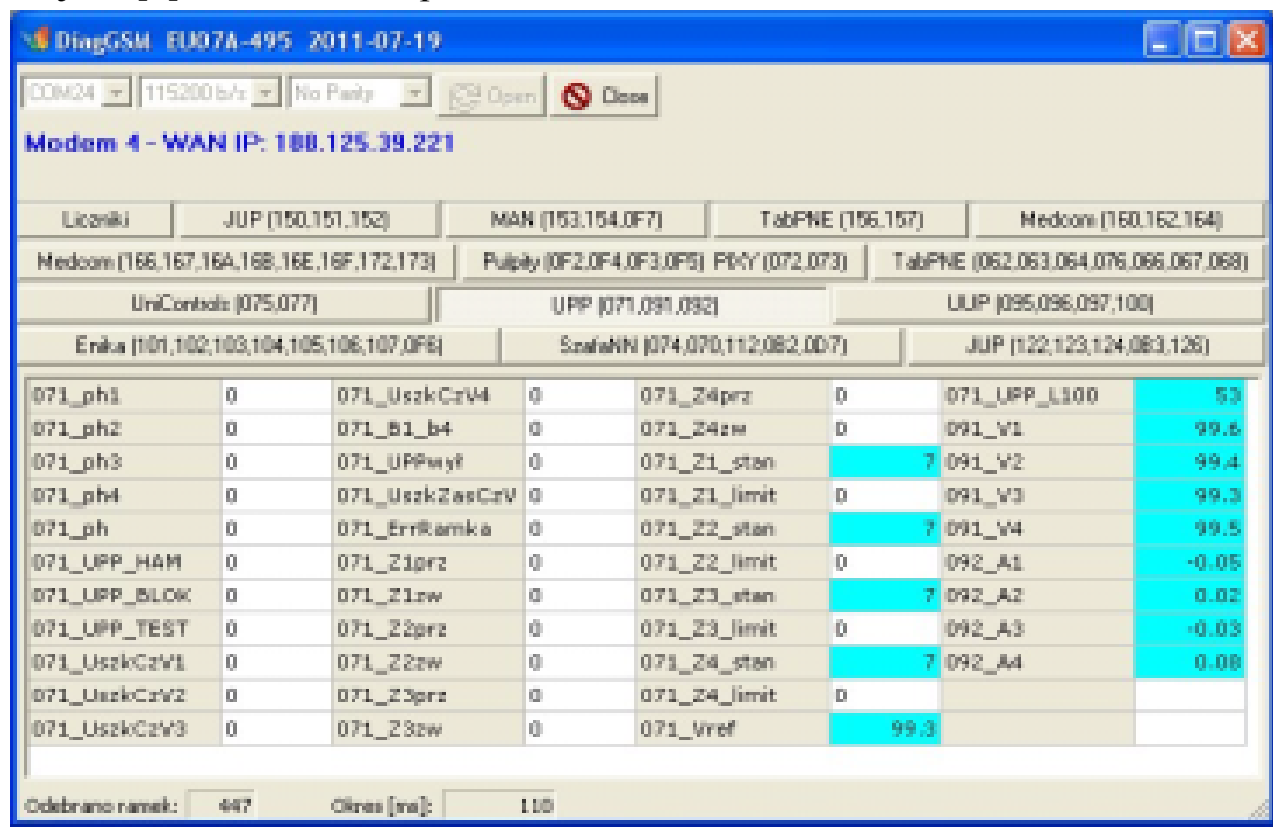

Rys. 4. Aplikacja diagnostyczna „EU07A DiagGSM" - zakładka z danymi z układu przeciwpoślizgowego IPS 
Po uruchomieniu programu należy nacisnać przycisk „Open”. Jeżeli modem GSM jest zasilony i znajduje się w zasięgu sieci GSM to nastapi otwarcie wirtualnego portu COM stowarzyszonego z modemem. Po poprawnym odebraniu całej ramki danych diagnostycznych program przeprowadza operację jej dekodowania z ciagu znaków ASCII na wartości poszczególnych danych diagnostycznych. Dane te są wyświetlane $\mathrm{w}$ odpowiednich komórkach tabeli oraz zapisywane do wynikowego pliku tekstowego. W celu lepszej czytelności tabel wprowadzono podświetlanie komórek zawierających wartości niezerowe: w przypadku zmiennych binarnych dana komórka podświetlana jest na zielono, natomiast $\mathrm{w}$ przypadku zmiennych liczbowych komórka podświetlana jest na niebiesko. Odświeżanie wartości zmiennych w tabeli następuje co 5 odebranych ramek (500 ms).

Po odebraniu 5000 ramek program kończy rejestrację, zamyka plik wynikowy i automatycznie rozpoczyna akwizycje danych do kolejnego pliku wyjściowego. W celu zakończenia działania programu należy w pierwszej kolejności zamknąć otwarty port przyciskiem „Close” a następnie zamknąć okno programu.

Nazwa wynikowego pliku tekstowego zapisywanego na komputerze diagnostycznym składa się z przedrostka identyfikującego pojazd oraz daty i czasu pobieranych $\mathrm{z}$ systemu operacyjnego komputera $\mathrm{w}$ chwili tworzenia pliku. Przyjęty format nazwy pliku gwarantuje jego jednoznaczną identyfikację oraz to, że żaden plik z danymi nie zostanie omyłkowo nadpisany. Format nazwy pliku z zapisanymi danymi diagnostycznymi jest następujący:

„Pojazd YYr-MM-DD hh_mm_ss.dia”, gdzie: Pojazd - nazwa pojazdu, YY - rok, $\mathrm{MM}$ - miesiąc, DD dzień, hh - godzina, mm - minuta, ss - sekunda, np.: „EU07-01 11r-12-26 08_29_36.dia”.

Zapisany plik tekstowy generowany przez program ma następująca strukturę: wiersze 1 do 8 : sygnatura pliku, wiersz 11: identyfikator pojazdu i/lub sterownika, wiersz 13: data utworzenia pliku, wiersz 14: czas utworzenia pliku, wiersz 16: opis danych diagnostycznych zapisanych w poszczególnych kolumnach, wiersze od 17 dane diagnostyczne. W wyniku analizy wykresów (przebiegów wybranych parametrów w czasie) stworzonych na podstawie tych plików można dokładnie prześledzić działanie danego podsystemu lokomotywy.

\section{Wykorzystanie danych diagnostycznych}

Poniżej przedstawiono dwa przykłady wykorzystania danych z układu diagnostycznego w rozwiązywaniu problemów technicznych zgłaszanych przez użytkowników.

\section{Zdarzenie nr 1:}

Użytkownik napisał: „W dniu 19-01-2012 ok. godz. 8:15 podczas hamowania czerwona wskazówka na

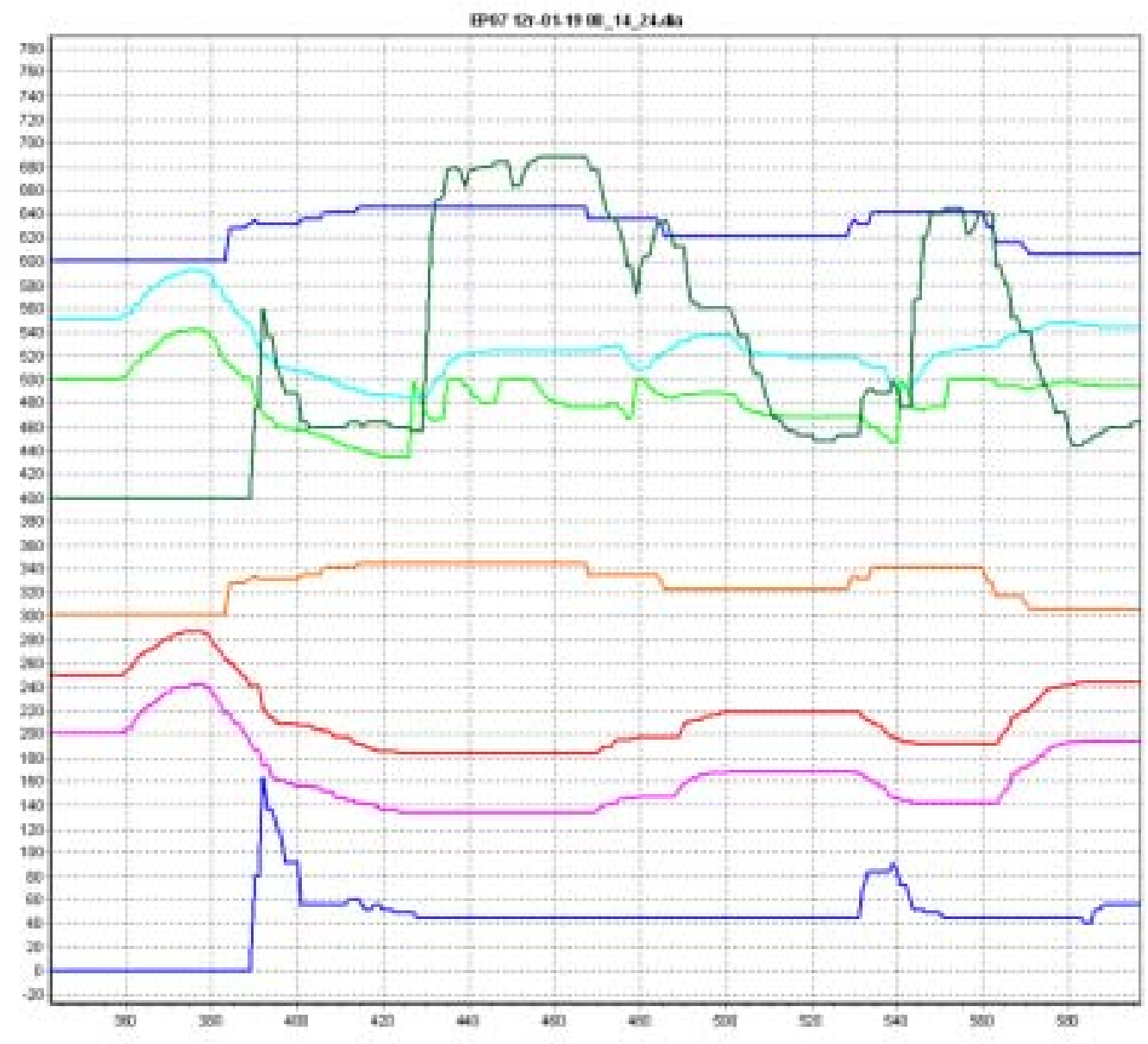

Rys. 5. Przebiegi wybranych danych $\mathrm{z}$ dnia 2012-01-19 godz. 08:14:24 
legenda do rys.5:

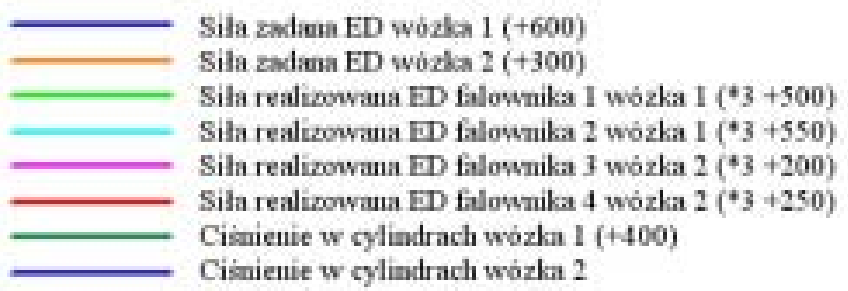

manometrze cylindrów hamulcowych była na ok. 0.5 bar, a żółta podskoczyła do 2-3 bar".

W celu przeanalizowania zgłoszonego zdarzenia wytypowano niezbędne zmienne i utworzono wykres ilustrujący ich przebieg (rys. 5) z wykorzystaniem pliku diagnostycznego „EP07 12r-01-19 08_14_24.dia".

Dla lepszej widoczności na wykresach przebiegi są pomnożone przez odpowiedni współczynnik i przesunięte względem siebie o różną wartość. Zapis „Siła realizowana ED falownika 1 wózka $1(* 3+500)$ " oznacza, że wartość siły przedstawiona na wykresie jest pomnożona przez współczynnik 3 i przesunięta o 500 .

Analiza powyższego przebiegu wykazała, że ciśnienie w cylindrach hamulcowych wózka nr 1 wzrosło na skutek ograniczenia mocy hamowania ED przez ten wózek. Mimo identycznej siły zadanej przez tablicę pneumatyczną dla hamulca ED obu wózków, siła realizowana hamowania ED wózka $\mathrm{nr} 1$ uległa nagłemu znacznemu ograniczeniu, co poskutkowało wzrostem ciśnienia w cylindrach hamulcowych wózka $\mathrm{nr} 1 \mathrm{z}$ wartości $50 \mathrm{kPa}$ do $280 \mathrm{kPa}$. Wzrost tego ciśnienia ma zapewnić realizację zadanej siły hamowania, która w tym przypadku musiała zostać zrealizowana tylko za pomocą hamulca pneumatycznego bez udziału hamulca ED. Ciśnienie w cylindrach hamulcowych wózka $\mathrm{nr} 2$ było utrzymywane na poziomie $50 \mathrm{kPa}$, gdyż większość siły hamowania tego wózka była realizowana przez sprawnie działający hamulec ED.

\section{Zdarzenie nr 2:}

Użytkownik napisał: „W dniu 27.012012 godz. ok.15:15 po uziemieniu lokomotywy a następnie wyłączeniu uziemienia po zakończeniu niezbędnych prac, nie można było podnieść pantografów. Pomogło wyłączenie i załączenie baterii".

W celu przeanalizowania zgłoszonego zdarzenia utworzono wykres ilustrujący ich przebieg (rys. 6) z wykorzystaniem pliku diagnostycznego „EP07 12r01-27 14_58_22.dia".

legenda do rys.6:

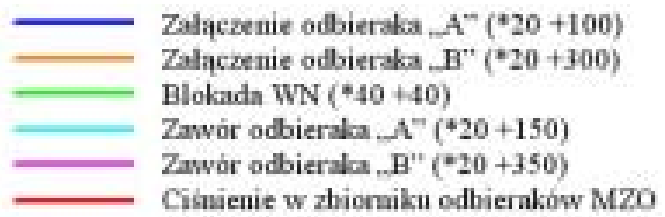

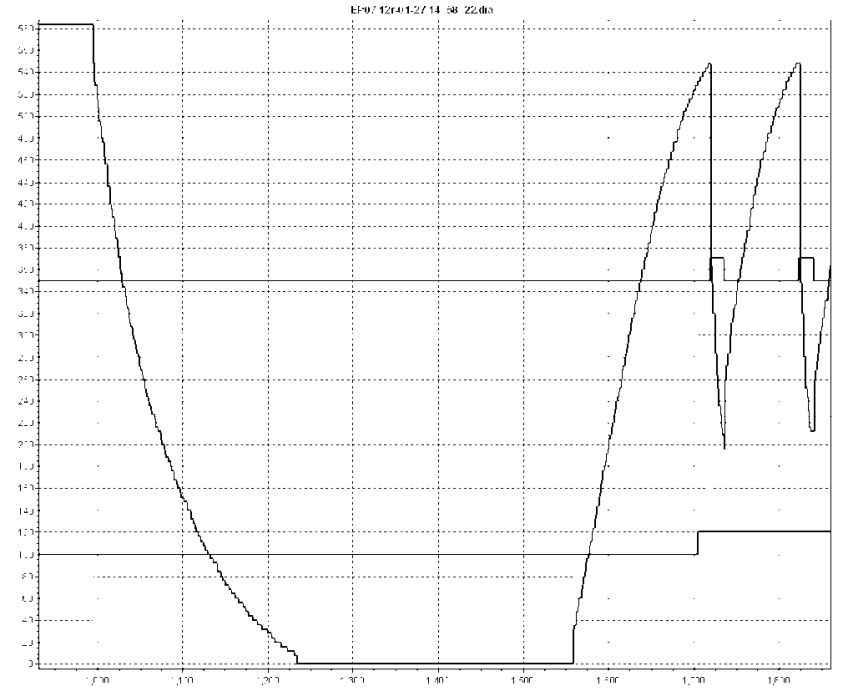

Rys. 6. Przebiegi wybranych danych z dnia 2012-01-27 godz. 14:58:22

Po analizie przebiegów ciśnień i sygnałów załączenia podniesienia odbieraków i ich wyłączników ciśnienia stwierdzono, że niemożność podniesienia odbieraków wynikała $\mathrm{z}$ faktu próby podniesienia naraz obydwu odbieraków $\mathrm{w}$ trakcie napełniania zbiornika odbieraków po zdjęciu blokady WN. Załączenie zaworów odbieraków nastapiło $\mathrm{z}$ opóźnieniem $\mathrm{w}$ stosunku do sygnałów załączenia odbieraków spowodowanym zbyt niskim ciśnieniem zbiornika odbieraków będącego jeszcze $w$ fazie napełniania. $\mathrm{W}$ takim przypadku wystapił $\mathrm{w}$ zbiorniku zasilającym odbieraki chwilowy duży spadek ciśnienia poniżej dopuszczalnej granicy, powodujący samoczynne opuszczanie załączonych odbieraków poprzez wyłączenie ich zaworów sterujących pomimo trwania żądania załączenia z pulpitu maszynisty. Tak więc udana próba podniesienia odbieraków po odłączeniu baterii mogła wyniknąć z tego, że załączenie ponowne nastąpiło po procesie napełnienia zbiornika odbieraka do wartości znamionowej lub z zachowaniem przerwy w sekwencji załączania, a nie wskutek resetu zasilania sterowników mikroprocesorowych.

Na dowód przedstawiono przebieg tych samych zmiennych (rys. 7) z wykorzystaniem pliku diagnostycznego „EP07 12r-01-27 18_29_37.dia” ilustrujący udaną próbe jednoczesnego podniesienia dwóch odbieraków przy napełnionym zbiorniku odbieraków.

legenda do rys.7:

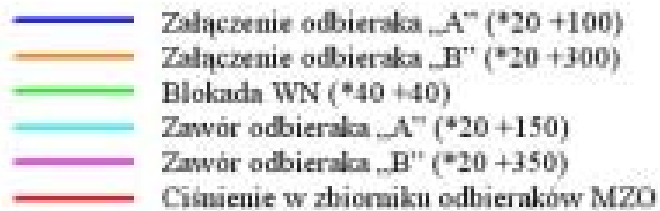




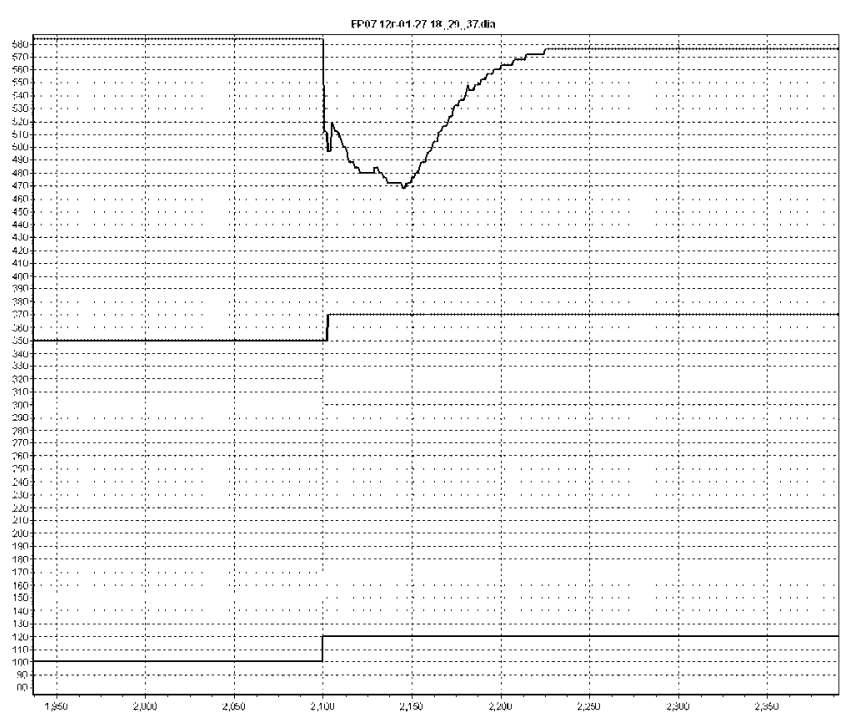

Rys. 7. Przebiegi wybranych danych z dnia 2012-01-27 godz. 18:29:37

Na podstawie powyższego przebiegu można potwierdzić, że równoczesne załączenie obydwu odbieraków przy w pełni napełnionym zbiorniku MZO nie powoduje spadku ciśnienia wyłączającego zawory odbieraków.

\section{Podsumowanie}

Diagnostyka zdalna umożliwia konstruktorom na bieżąco podgląd działania lokomotywy podczas jej jazd eksploatacyjnych oraz analizę pojawiających się usterek i błędów.

Jest nieocenionym źródłem danych diagnostycznych prostych jak i w postaci gotowych wskaźników i innych parametrów oceny umożliwiających prognozowanie stanu wybranych urządzeń na podstawie analizy trendów oraz raportów z okresowej kontroli kluczowych parametrów procesu. Postać strumienia danych diagnostycznych zależy od konkretnego systemu diagnostycznego wdrożonego na pojeździe. W omawianych przykładach wykorzystywany był prosty strumień danych wymagający automatyzacji procesu tworzenia parametrów oceny $\mathrm{w}$ celu przygotowywaniu trendów oraz ich analizy.
System diagnozowania zdalnego umożliwia szkolenie i pomoc maszynistom na etapie poznawania nowego pojazdu. Ponadto integrator projektu posiada możliwość sprawnego wykrywania nieprawidłowości w działaniu poszczególnych podzespołów jeszcze na etapie eksploatacji obserwowanej dzięki możliwości szczegółowej analizy zdarzeń pojawiających się sporadycznie. Nie jest bowiem wymagane czasochłonne powtarzanie określonych czynności w celu umożliwienia wielokrotnych analiz raz zauważonej nieprawidłowości w działaniu.

W lokomotywie EU07A po raz pierwszy zabudowano modem GSM na stałe. Dzięki temu możemy na bieżąco śledzić działanie całego systemu sterowania lokomotywy (kilkanaście sterowników wymieniających dane po magistrali CAN).

Transmisja danych diagnostycznych za pośrednictwem sieci GSM umożliwia zbieranie danych diagnostycznych przez całą dobę i nie wymaga obecności na pojeździe wykwalifikowanego serwisu. Niezmiernie istotny jest również fakt uzyskania obiektywnych danych pomiarowych zamiast subiektywnych wrażeń personelu obsługującego pojazd.

\section{Lit e r a t u ra}

[1] Czerwiński J., Lastowski M., Krajewski S., Szymczak J., Modernizacja lokomotywy serii EU07, TTS 3/2011.

[2] Haba M., Iwanowski J., Zdalna diagnostyka mikroprocesorowych systemów sterowania pojazdów szynowych za pośrednictwem sieci telefonii komórkowej GSM, XIII Międzynarodowa Konferencja Naukowa „QSET 2011", Kraków-Niepołomice 2011.

[3] ELMARK Automatyka, MOXA - kompleksowe rozwiqzania dla komunikacji przemystowej, folder promocyjny. 